Original Research Article

\title{
Cost effective analysis of tab. nitrofurantoin vs. inj. ceftriaxone as an empirical therapy in patients of urinary tract infection at a tertiary health care centre
}

\author{
Nikhil S. Yadav*, Swanand S. Pathak
}

Department of Pharmacology, Jawaharlal Nehru Medical College, Sawangi (Meghe), Wardha, Maharashtra, India

Received: 28 September 2018 Accepted: 25 October 2018

*Correspondence to: Dr. Nikhil S. Yadav, Email:mysticfugue@gmail.com

Copyright: (C) the author(s), publisher and licensee Medip Academy. This is an openaccess article distributed under the terms of the Creative Commons Attribution NonCommercial License, which permits unrestricted noncommercial use, distribution, and reproduction in any medium, provided the original work is properly cited.

\begin{abstract}
Background: Urinary tract infections (UTI) are commonly seen in adults, Urinary tract infection and asymptomatic bacteriuria in adults are a significant health care burden. In a developing country it is necessary to minimize the cost of therapy while giving maximum health benefits to the patient. Appropriate antimicrobial selection is clearly important, as treatment failures will increase the cost of care and result in additional morbidity for patients. Empirical treatment of urinary tract infection is common at tertiary health care center, authors conducted a pharmacoeconomic study to evaluate cost effectiveness of the empirical treatment.
\end{abstract}

Methods: Patients with similar symptoms suffering from UTI were divided into 5 groups with 10 patients in each group. Each group was subdivided into two subgroups with subgroup A having five patients receiving tab nitrofurantoin and subgroup B having 5 patients receiving inj ceftriaxone. Out of the total cost of therapy, percentage of cost attributed to tab nitrofurantoin was compared with inj ceftriaxone. Most cost-effective antibiotic was analysed. Average number of admission days for groups of UTI patients receiving tab nitrofurantoin and inj ceftriaxone were calculated and compared. Group of UTI patients receiving antibiotic with least number of admission days was calculated.

Results: Percentage of cost attributed to Nitrofurantoin therapy out of total cost in urinary tract infection patient was less than percentage of cost attributed to inj Ceftriaxone in all five groups of patients and was found to be statistically significant ( $\mathrm{p}<0.05)$. However, there was no statistically significant difference in average number of admission (IPD) days between groups of patients receiving tab nitrofurantoin and inj ceftriaxone $(\mathrm{p}>0.05)$.

Conclusions: In current study authors found tab nitrofurantoin to be more cost effective than inj ceftriaxone as an empirical therapy in UTI patients.

Keywords: Cost effectiveness, Nitrofurantoin, Urinary tract infection

\section{INTRODUCTION}

Urinary tract infection involves upper urinary tract (kidneys and ureter) and/or lower urinary tract (urethra and urinary bladder), urinary tract infections are caused by wide range of pathogens including Escherichia coli, Klebsiella pneumoniae, Proteus mirabilis, Staphylococcus aureus, clinically urinary tract infections are divided into complicated and uncomplicated urinary tract infections. ${ }^{1}$ Uncomplicated urinary tract infections takes place in healthy individuals with no structural defects and neurological deficits, complicated UTI are defined as those compromising host defence, urinary tract (obstruction) and neurological integrity which leads to urinary tract infections. ${ }^{2}$ Urinary tract infections are common in developing countries affecting women more than men, it is necessary to minimize the cost of therapy while providing optimum health benefits to the patients. Patients of UTI are prone to recurrence and high costs of treatment leads to increase burden of costs of treatment on patients. 
Urinary tract infections are a frequent cause of hospitalisation and have a great economic impact on healthcare systems. The annual cost of UTI acquired through community is significant and goes beyond 1.6 million dollars. ${ }^{3}$ In developing countries because of increased antimicrobial resistance and increased cost of treatment, patients are left with few therapeutic options. ${ }^{4,5}$

Intravenous antibiotic given in urinary tract infection requires admission of patient, despite admission the other costs incurred by the patient is increased i.e. price of intravenous antibiotics and cost of syringes and needles. Injection ceftriaxone shows wide spectrum of antibiotic activity especially in urinary tract infection, it is highly efficacious against many gram negative UTI causing Enterobacteriaceae i.e. E coli, Klebsiella, however increased cost of antibiotic and other cost (syringes and needles) required for ceftriaxone should restrict its use in developing country like India. ${ }^{6}$

Nitrofurantoin has been found to be effective in causing remissions of symptoms in patients of urinary tract infections. ${ }^{7}$ Nitrofurantoin is a bactericidal antibiotic with a broad-spectrum activity and can be used to treat urinary tract infection caused by Enterobacter spp, Klebsiella spp, Staphylococcus aureus spp and Enterococcus spp. Nitrofurantoin is the first choice recommended for treatment of uncomplicated cystitis and pyelonephritis in women. Nitrofurantoin has become the choice of antibiotic in UTI due multi drug resistant pathogens, especially in developing countries like India and is highly effective against gram negative and gram positive bacteria causing UTI and is also cost effective with fewer adverse effects. ${ }^{8}$

Pharmacoeconomics is the application of economics to assess the pharmaceutical and health care products that helps evaluate economic, clinical and humanistic outcomes of health care products and interventions. In a developing country like India where there are so many prevalent infections and limited resources, study of

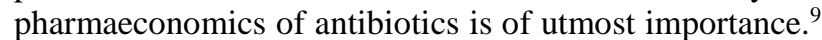
In authors' tertiary health care center antibiotics are sometimes prescribed empirically with most of the patients of UTI being admitted, therefore we planned a study to compare cost effectiveness of two most commonly prescribed antibiotics for urinary tract infection i.e. nitrofurantoin and ceftriaxone.

The aim of the present study was to Compare cost effectiveness of tab. nitrofurantoin with inj. ceftriaxone in adult IPD patients suffering from Urinary tract infection.

\section{Objectives}

- To calculate percentage of cost of total therapy attributed to tab. nitrofurantoin

- To calculate percentage of cost of total therapy of attributed to inj. ceftriaxone

- To compare percentage of cost of total therapy attributed to tab. nitrofurantoin with inj. ceftriaxone and find out most cost-effective antibiotic for urinary tract infection

- $\quad$ To find out average number of admission days until patients (receiving tab nitrofurantoin) became symptom free

- To find out average number of admission days until patients (receiving inj. ceftriaxone) became symptom free

- To compare average number of admission days of patients receiving tab nitrofurantoin with average number of admission days of patients receiving inj ceftriaxone and find out the antibiotic with least number of admission days

\section{METHODS}

The study was undertaken after receiving letter of approval from Institutional Ethical Committee, DMIMS, dated 31/03/2017 with Ref. No. DMIMS(DU)/IEC/2017$18 / 6348$.

Table 1: patients were grouped into five groups based on symptoms each group divided into two subgroups.

\begin{tabular}{|c|c|c|}
\hline Groups & Subgroup & Symptoms \\
\hline \multirow{2}{*}{ Group I } & $\begin{array}{l}\text { Subgroup I A } \\
\text { (receiving } \\
\text { nitrofurantoin) }\end{array}$ & \multirow{2}{*}{$\begin{array}{l}\text { Burning } \\
\text { micturition, lower } \\
\text { abdominal pain, } \\
\text { increased } \\
\text { frequency of } \\
\text { urination, fever }\end{array}$} \\
\hline & $\begin{array}{l}\text { Subgroup I B } \\
\text { (receiving ceftriaxone) }\end{array}$ & \\
\hline \multirow[t]{2}{*}{ Group II } & $\begin{array}{l}\text { Subgroup II A } \\
\text { (receiving } \\
\text { nitrofurantoin) }\end{array}$ & \multirow{2}{*}{$\begin{array}{l}\text { Burning } \\
\text { micturition, fever, } \\
\text { increased } \\
\text { frequency of } \\
\text { urination }\end{array}$} \\
\hline & $\begin{array}{l}\text { Subgroup II B } \\
\text { (receiving ceftriaxone) }\end{array}$ & \\
\hline \multirow{2}{*}{ Group III } & $\begin{array}{l}\text { Subgroup III A } \\
\text { (receiving } \\
\text { nitrofurantoin) }\end{array}$ & \multirow{2}{*}{$\begin{array}{l}\text { Burning } \\
\text { micturition, lower } \\
\text { abdominal pain, } \\
\text { increased } \\
\text { frequency of } \\
\text { urination }\end{array}$} \\
\hline & $\begin{array}{l}\text { Subgroup III B } \\
\text { (receiving ceftriaxone) }\end{array}$ & \\
\hline \multirow[t]{2}{*}{ Group IV } & $\begin{array}{l}\text { Subgroup IV A } \\
\text { (receiving } \\
\text { nitrofurantoin) }\end{array}$ & \multirow{2}{*}{$\begin{array}{l}\text { Lower abdominal } \\
\text { pain, increased } \\
\text { frequency of } \\
\text { urination, fever }\end{array}$} \\
\hline & $\begin{array}{l}\text { Subgroup IV B } \\
\text { (receiving ceftriaxone) }\end{array}$ & \\
\hline \multirow[t]{2}{*}{ Group V } & $\begin{array}{l}\text { Subgroup V A } \\
\text { (receiving } \\
\text { nitrofurantoin) }\end{array}$ & \multirow{2}{*}{$\begin{array}{l}\text { Burning } \\
\text { micturition, } \\
\text { increased } \\
\text { frequency of } \\
\text { urination }\end{array}$} \\
\hline & $\begin{array}{l}\text { Subgroup V B } \\
\text { (receiving ceftriaxone) }\end{array}$ & \\
\hline
\end{tabular}

The study was performed on 50 cases of urinary tract infection in adult population admitted at Acharya Vinoba Bhave rural hospital (Sawangi). The study was carried out from $1^{\text {st }}$ April 2017 till $1^{\text {st }}$ June 2017 (two months). Inclusion criteria for this study was male and female patient admitted in medicine/surgery/Obgy ward with patient age $>18$ years. Exclusion criteria for the study was 
patient age less than 18 years, patients suffering from complicated urinary tract infection, patients not willing to participate in the study and OPD patients. This study was an observational study with sample size of 50 patients. Patients with similar symptoms suffering from UTI were divided into 5 groups (Figure1) with 10 patients in each group. Each group was subdivided into two subgroups with subgroup A having five patients receiving tab nitrofurantoin and subgroup B having 5 patients receiving inj ceftriaxone as shown in Table 1. Five patients from each group were receiving Tab Nitrofurantoin and Five patients were getting Inj Ceftriaxone as an empirical therapy for UTI. Average total cost of therapy (which includes cost of all medicines for UTI patient), average total cost of antibiotic therapy in each group (ceftriaxone or nitrofurantoin) and average total no of IPD (admission) days until patients became symptom free were calculated. Out of the total cost of therapy, percentage of cost attributed to tab nitrofurantoin was compared with inj ceftriaxone. Most cost-effective antibiotic was analysed. Average number of admission days for groups of UTI patients receiving tab nitrofurantoin and inj ceftriaxone were calculated and compared. Group of UTI patients receiving antibiotic (nitrofurantoin or ceftriaxone) with least number of admission (IPD) days was calculated.

\section{Statistical analysis}

Statistical analysis was done by using descriptive and inferential statistics using student's unpaired t test and software used in the analysis was SPSS 22.0 version and $\mathrm{p}<0.05$ is considered as level of significance.

\section{RESULTS}

The average number of admission days of urinary tract infection patients in group IA (receiving nitrofurantoin) was 4.4 days, total average cost of therapy for urinary tract infection in group IA was 277 rupees out of which 70.4 rupees was attributed to nitrofurantoin therapy. Percentage of cost attributed to nitrofurantoin out of total cost of therapy was $26 \%$ as shown in Table 2.

The average number of admission days of group IB (receiving inj ceftriaxone) was 5.2 days, total average cost of therapy for urinary tract infection in group IB was 911 rupees out of which 676 rupees was attributed to ceftriaxone therapy. Percentage of cost attributed to ceftriaxone out of total cost of therapy was $75 \%$ as shown in Table 3.

By using unpaired student $t$ test statistically significant difference was found between average cost (in percentage) attributed to injection ceftriaxone (group IB) and tablet nitrofurantoin (group IA) (p-value <0.05) Table 12. By using unpaired student $t$ test no statistical significant difference between average number of admission days was found within each group receiving Inj ceftriaxone (group IB) and tablet nitrofurantoin (group IA) ( $\mathrm{p}$-value $>0.05$ ) Table 13.

Table 2: No of admission (IPD) days of UTI patients in group IA and percentage of cost of therapy attributed to nitrofurantoin out of total cost.

\begin{tabular}{|lllll|}
\hline Age $(\mathbf{y r s})$ & No. of IPD days & $\begin{array}{l}\text { Cost of } \\
\text { nitrofurantoin } \\
\text { (rupees) }\end{array}$ & $\begin{array}{l}\text { Total cost of therapy for } \\
\text { UTI (rupees) }\end{array}$ & $\begin{array}{l}\text { Percentage of cost attributed to } \\
\text { nitrofurantoin out of total cost } \\
(\%)\end{array}$ \\
\hline 45 & 3 & 48 & 213 & 23 \\
\hline 42 & 4 & 64 & 258 & 25 \\
\hline 47 & 4 & 64 & 260 & 25 \\
\hline 48 & 5 & 80 & 304 & 27 \\
\hline 44 & 6 & 96 & 349 & 28 \\
\hline Avg. & 4.4 days & 70.4 rupees & 277 rupees \\
\hline
\end{tabular}

Table 3: No of admission (IPD) days of UTI patients in group IB and percentage of cost of therapy attributed to ceftrixone out of total cost.

\begin{tabular}{|lllll|}
\hline Age (yrs) & No. of IPD days & $\begin{array}{l}\text { Cost of ceftrixone } \\
\text { (rupees) }\end{array}$ & $\begin{array}{l}\text { Total cost of therapy for } \\
\text { UTI (rupees) }\end{array}$ & $\begin{array}{l}\text { Percentage of cost attributed to } \\
\text { ceftriaxone out of total cost }(\%)\end{array}$ \\
\hline 60 & 6 & 780 & 1040 & 76 \\
\hline 55 & 5 & 650 & 880 & 74 \\
\hline 48 & 4 & 520 & 720 & 73 \\
\hline 56 & 5 & 650 & 876 & 75 \\
\hline 58 & 6 & 780 & 1040 & $75 \%$ \\
\hline Avg. & 5.2 days & 676 rupees & 911 rupees \\
\hline
\end{tabular}


Table 4: No of admission (IPD) days of UTI patients in group IIA and percentage of cost of therapy attributed to nitrofurantoin out of total cost.

\begin{tabular}{|lllll|}
\hline Age (yrs) & No. of IPD days & $\begin{array}{l}\text { Cost of } \\
\text { nitrofurantoin } \\
\text { (rupees) }\end{array}$ & $\begin{array}{l}\text { Total cost of therapy for } \\
\text { UTI (rupees) }\end{array}$ & $\begin{array}{l}\text { Percentage of cost attributed to } \\
\text { nitrofurantoin out of total cost } \\
(\%)\end{array}$ \\
\hline 26 & 4 & 64 & 264 & 25 \\
\hline 45 & 4 & 64 & 274 & 25 \\
\hline 50 & 5 & 80 & 304 & 27 \\
\hline 47 & 4 & 64 & 269 & 24 \\
\hline 44 & 4 & 64 & 260 & 25 \\
\hline Avg. & 4.2 days & 67.2 rupees & 274.2 rupees & $25 \%$ \\
\hline
\end{tabular}

Table 5: No of admission (IPD) days of UTI patients in group IIB and percentage of cost of therapy attributed to ceftrixone out of total cost.

\begin{tabular}{|lllll|}
\hline Age (yrs) & No. of IPD days & $\begin{array}{l}\text { Cost of ceftrixone } \\
\text { (rupees) }\end{array}$ & $\begin{array}{l}\text { Total cost of therapy for } \\
\text { UTI (rupees) }\end{array}$ & $\begin{array}{l}\text { Percentage of cost attributed to } \\
\text { ceftriaxone out of total cost }\end{array}$ \\
\hline 40 & 4 & 390 & 555 & 71 \\
\hline 44 & 4 & 520 & 720 & 73 \\
\hline 21 & 5 & 650 & 885 & 74 \\
\hline 55 & 5 & 650 & 876 & 75 \\
\hline 48 & 4 & 520 & 725 & 72 \\
\hline Avg. & 4.4 days & 546 rupees & 752.2 rupees & $73 \%$ \\
\hline
\end{tabular}

The average number of admission days of urinary tract infection patients in group IIA (receiving nitrofurantoin) was 4.2 days, total average cost of therapy for urinary tract infection in group IIA was 274.2 rupees out of which 67.2 rupees was attributed to nitrofurantoin therapy. Percentage of cost attributed to nitrofurantoin out of total cost of therapy was $25 \%$ as shown in Table 4 .

The average number of admission days of group IIB (receiving inj ceftriaxone) was 4.4 days, total average cost of therapy for urinary tract infection in group IIB was 752.2 rupees out of which 546 rupees was attributed to ceftriaxone therapy. Percentage of cost attributed to ceftriaxone out of total cost of therapy was $73 \%$ as shown in Table 5.

By using unpaired student $\mathrm{t}$ test statistically significant difference was found between average cost (in percentage) attributed to injection ceftriaxone (group IIB) and tablet nitrofurantoin (group IIA) (p-value <0.05) as shown in Table 12. By using unpaired student $t$ test no statistical significant difference between average number of admission days was found within each group receiving inj ceftriaxone (group IIB) and tablet nitrofurantoin (group IIA) ( $\mathrm{p}$-value $>0.05$ ) as shown in Table 13 .

The average number of admission days of urinary tract infection patients in group IIIA (receiving nitrofurantoin) was 5.4 days, total average cost of therapy for urinary tract infection in group IIIA was 312.40 rupees out of which 86.4 rupees was attributed to nitrofurantoin therapy.
Percentage of cost attributed to nitrofurantoin out of total cost of therapy was $28 \%$ as shown in Table 6.

The average number of admission days of group IIIB (receiving inj ceftriaxone) was 5.6 days, total average cost of therapy for urinary tract infection in group IIIB was 984 rupees out of which 728 rupees was attributed to ceftriaxone therapy. Percentage of cost attributed to ceftriaxone out of total cost of therapy was $74 \%$ as shown in Table 7.

By using unpaired student $\mathrm{t}$ test statistically significant difference was found between average cost (in percentage) attributed to injection ceftriaxone (group IIIB) and tablet nitrofurantoin (group IIIA) (p-value <0.05) as shown in Table 12. By using unpaired student $t$ test no statistical significant difference between average number of admission days was found within each group receiving inj ceftriaxone (group IIIB) and tablet nitrofurantoin (group IIIA) (p-value >0.05) as shown in Table 13.

The average number of admission days of urinary tract infection patients in group IVA (receiving nitrofurantoin) was 5.2 days, total average cost of therapy for urinary tract infection in group IVA was 339.5 rupees out of which 83.2 rupees was attributed to nitrofurantoin therapy. Percentage of cost attributed to nitrofurantoin out of total cost of therapy was $25 \%$ as shown in Table 8.

The average number of admission days of group IVB (receiving inj ceftriaxone) was 5.4 days, total average cost of therapy for urinary tract infection in Group IVB was 
980.6 rupees out of which 702 rupees was attributed to ceftriaxone therapy. Percentage of cost attributed to ceftriaxone out of total cost of therapy was $72 \%$, as shown in Table 9. By using unpaired student $t$ test statistically significant difference was found between average cost (in percentage) attributed to injection ceftriaxone (group IVB) and tablet nitrofurantoin (group IVA) (p-value <0.05) as shown in Table 12. By using unpaired student $t$ test no statistical significant difference between average number of admission days was found within each group receiving inj ceftriaxone (group IVB) and Tablet nitrofurantoin (group IVA) (p-value >0.05) as shown in Table 13.

Table 6: No of admission (IPD) days of UTI patients in group IIIA and percentage of cost of therapy attributed to nitrofurantoin out of total cost.

\begin{tabular}{|lllll|}
\hline Age (yrs) & $\begin{array}{l}\text { No. of IPD } \\
\text { days }\end{array}$ & $\begin{array}{l}\text { Cost of nitrofurantoin } \\
\text { (rupees) }\end{array}$ & $\begin{array}{l}\text { Total cost of therapy } \\
\text { for UTI (rupees) }\end{array}$ & $\begin{array}{l}\text { Percentage of cost attributed to } \\
\text { nitrofurantoin out of total cost (\%) }\end{array}$ \\
\hline 35 & 5 & 80 & 294 & 28 \\
\hline 45 & 5 & 80 & 294 & 28 \\
\hline 37 & 6 & 96 & 340 & 29 \\
\hline 45 & 5 & 80 & 294 & 28 \\
\hline 44 & 6 & 96 & 340 & 29 \\
\hline Avg. & 5.4 days & 86.4 rupees & 312.40 rupees & $28 \%$ \\
\hline
\end{tabular}

Table 7: No of admission (IPD) days of UTI patients in group IIIB and percentage of cost of therapy attributed to ceftrixone out of total cost.

\begin{tabular}{|lllll|}
\hline Age (yrs) & $\begin{array}{l}\text { No. of IPD } \\
\text { days }\end{array}$ & $\begin{array}{l}\text { Cost of ceftrixone } \\
\text { (rupees) }\end{array}$ & $\begin{array}{l}\text { Total cost of therapy } \\
\text { for UTI (rupees) }\end{array}$ & $\begin{array}{l}\text { Percentage of cost attributed to } \\
\text { ceftriaxone out of total cost (\%) }\end{array}$ \\
\hline 50 & 5 & 650 & 864 & 76 \\
\hline 36 & 6 & 780 & 1024 & 76 \\
\hline 54 & 6 & 780 & 1124 & 70 \\
\hline 56 & 5 & 650 & 864 & 76 \\
\hline 48 & 6 & 780 & 1024 & 75 \\
\hline Avg. & 5.6 days & 728 rupees & 984 rupees & $74 \%$ \\
\hline
\end{tabular}

Table 8: No of admission (IPD) days of UTI patients in group IVA and percentage of cost of therapy attributed to nitrofurantoin out of total cost.

\begin{tabular}{|lllll|}
\hline Age (yrs) & $\begin{array}{l}\text { No. of IPD } \\
\text { days }\end{array}$ & $\begin{array}{l}\text { Cost of nitrofurantoin } \\
\text { (rupees) }\end{array}$ & $\begin{array}{l}\text { Total cost of therapy } \\
\text { for UTI (rupees) }\end{array}$ & $\begin{array}{l}\text { Percentage of cost attributed to } \\
\text { nitrofurantoin out of total cost (\%) }\end{array}$ \\
\hline 56 & 5 & 80 & 332 & 24 \\
\hline 57 & 6 & 96 & 376 & 26 \\
\hline 53 & 5 & 80 & 301 & 27 \\
\hline 38 & 5 & 80 & 388 & 21 \\
\hline 46 & 5 & 80 & 301 & 27 \\
\hline Avg. & 5.2 days & 83.2 rupees & 339.5 rupees & $25 \%$ \\
\hline
\end{tabular}

Table 9: No of admission (IPD days) of UTI patients in group IVB and percentage of cost of therapy attributed to ceftrixone out of total cost.

\begin{tabular}{|lllll|}
\hline Age (yrs) & $\begin{array}{l}\text { No. of IPD } \\
\text { days }\end{array}$ & $\begin{array}{l}\text { Cost of ceftrixone } \\
\text { (rupees) }\end{array}$ & $\begin{array}{l}\text { Total cost of therapy } \\
\text { for UTI (rupees) }\end{array}$ & $\begin{array}{l}\text { Percentage of cost attributed to } \\
\text { ceftriaxone out of total cost }(\%)\end{array}$ \\
\hline 60 & 5 & 650 & 902 & 72 \\
\hline 56 & 6 & 780 & 1112 & 70 \\
\hline 55 & 6 & 780 & 1060 & 74 \\
\hline 47 & 5 & 650 & 871 & 75 \\
\hline 52 & 5 & 650 & 958 & 68 \\
\hline Avg. & 5.4days & 702 rupees & 980.6 rupees & $72 \%$ \\
\hline
\end{tabular}


The average number of admission (IPD) days of urinary tract infection patients in group VA (receiving nitrofurantoin) was 4.4 days, total average cost of therapy for urinary tract infection in Group VA was 227.60 rupees out of which 67.2 rupees was attributed to nitrofurantoin therapy. Percentage of cost attributed to nitrofurantoin out of total cost of therapy was $30 \%$, as shown in Table 10 .
The average number of admission (IPD) days of group VB (receiving inj ceftriaxone) was 5 days, total average cost of therapy for urinary tract infection in Group VB was 848 rupees out of which 650 rupees was attributed to ceftriaxone therapy. Percentage of cost attributed to ceftriaxone out of total cost of therapy was $77 \%$ as shown in Table 12.

Table 10: No of admission (IPD days) of UTI patients in group VA and percentage of cost of therapy attributed to nitrofurantoin out of total cost.

\begin{tabular}{|lllll|}
\hline Age $(\mathbf{y r s})$ & $\begin{array}{l}\text { No. of IPD } \\
\text { days }\end{array}$ & $\begin{array}{l}\text { Cost of ceftrixone } \\
\text { (rupees) }\end{array}$ & $\begin{array}{l}\text { Total cost of therapy } \\
\text { for UTI (rupees) }\end{array}$ & $\begin{array}{l}\text { Percentage of cost attributed to } \\
\text { nitrofurantoin out of total cost }(\%)\end{array}$ \\
\hline 20 & 5 & 80 & 208 & 38 \\
\hline 36 & 4 & 64 & 221 & 29 \\
\hline 45 & 4 & 64 & 244 & 26 \\
\hline 48 & 4 & 48 & 244 & 20 \\
\hline 55 & 5 & 80 & 221 & 36 \\
\hline Avg. & 4.4 days & 67.2 rupees & 227.60 rupees & $30 \%$ \\
\hline
\end{tabular}

Table 11: No of admission (IPD) days of UTI patients in group VB and percentage of cost of therapy attributed to ceftrixone out of total cost.

\begin{tabular}{|lllll|}
\hline Age (yrs) & $\begin{array}{l}\text { No. of IPD } \\
\text { days }\end{array}$ & $\begin{array}{l}\text { Cost of ceftrixone } \\
\text { (rupees) }\end{array}$ & $\begin{array}{l}\text { Total cost of therapy } \\
\text { for UTI (rupees) }\end{array}$ & $\begin{array}{l}\text { Percentage of cost attributed to } \\
\text { ceftriaxone out of total cost }(\%)\end{array}$ \\
\hline 45 & 5 & 650 & 850 & 77 \\
\hline 53 & 6 & 780 & 990 & 79 \\
\hline 37 & 5 & 650 & 820 & 79 \\
\hline 43 & 5 & 650 & 860 & 76 \\
\hline 60 & 4 & 520 & 720 & 72 \\
\hline Avg. & 5 days & 650 rupees & 848 rupees & $77 \%$ \\
\hline
\end{tabular}

Table 12: Comparison of cost effectiveness ( $\%$ of cost attributed to each antibiotic) within each group (between ceftriaxone and nitrofurantoin).

\begin{tabular}{|lllll|}
\hline & Nitrofurantoin & Ceftriaxone & t-value & p-value \\
\hline Group I & $25.60 \pm 1.94$ & $74.60 \pm 1.14$ & 48.51 & $0.0001, \mathrm{~S}$ \\
\hline Group II & $25.20 \pm 1.09$ & $73 \pm 1.58$ & 55.56 & $0.0001, \mathrm{~S}$ \\
\hline Group III & $28.40 \pm 0.54$ & $74.60 \pm 2.60$ & 38.77 & $0.0001, \mathrm{~S}$ \\
\hline Group IV & $25 \pm 2.55$ & $71.80 \pm 2.86$ & 27.29 & $0.0001, \mathrm{~S}$ \\
\hline Group V & $27.80 \pm 5.76$ & $76.60 \pm 2.88$ & 16.93 & $0.0001, \mathrm{~S}$ \\
\hline
\end{tabular}

Table 13: Comparison of average number of admission days (IPD) within each group (between ceftriaxone and nitrofurantoin).

\begin{tabular}{|lllll|}
\hline & Nitrofurantoin & Ceftriaxone & t-value & p-value \\
\hline Group I & $4.40 \pm 1.14$ & $5.20 \pm 0.83$ & 1.26 & 0.24, NS \\
\hline Group II & $4.20 \pm 0.44$ & $4.40 \pm 0.54$ & 0.63 & 0.54, NS \\
\hline Group III & $5.40 \pm 0.54$ & $5.60 \pm 0.54$ & 0.57 & 0.58, NS \\
\hline Group IV & $5.20 \pm 0.44$ & $5.40 \pm 0.54$ & 0.63 & 0.54, NS \\
\hline Group V & $4.40 \pm 0.54$ & $5 \pm 0.70$ & 1.50 & 0.17, NS \\
\hline
\end{tabular}

By using unpaired student $\mathrm{t}$ test statistically significant difference was found between average cost (in percentage) attributed to injection ceftriaxone (group IVB) and tablet nitrofurantoin (group IVA) (p-value <0.05) as shown in 
Table 12. By using unpaired student t test no statistical significant difference between average number of admission (IPD) days was found within each group receiving inj ceftriaxone (group IVB) and Tablet nitrofurantoin (group IVA) (p-value $>0.05$ ) as shown in Table 13.

Average cost (in percentage) out of total cost attributed to nitrofurantoin and ceftriaxone in group I was $25.60 \pm 1.94$ and $74.60 \pm 1.14$ respectively, in group II it was $25.20 \pm 1.09$ and $73 \pm 1.58$ respectively, in group III it was $28.40 \pm 0.54$ and $74.60 \pm 2.60$ respectively, in group IV it was $25 \pm 2.55$ and $71.80 \pm 2.86$ respectively, in group $\mathrm{V}$ it was $27.80 \pm 5.76$ and $76.60 \pm 2.88$ respectively. By using unpaired student $t$ test statistically significant difference was found between average cost (in percentage) attributed to injection ceftriaxone and tablet nitrofurantoin ( $p$-value $<0.05)$ in each group. Avera average number of admission (IPD) days in patients receiving nitrofurantoin and ceftriaxone in group I was $4.40 \pm 1.14$ and $5.20 \pm 0.83$ respectively ,in group II it was $4.20 \pm 0.44$ and $4.40 \pm 0.54$ respectively, in group III it was $5.40 \pm 0.54$ and $5.60 \pm 0.54$ respectively, in group IV it was $5.20 \pm 0.44$ and $5.40 \pm 0.54$ respectively, in group $\mathrm{V}$ it was $4.40 \pm 0.54$ and $5 \pm 0.70$ respectively. By using unpaired student $\mathrm{t}$ test no statistically significant difference between average number of admission (IPD) days was found within each group receiving Inj ceftriaxone and tablet nitrofurantoin ( $\mathrm{p}$-value $>0.05$ ) in each group.

\section{DISCUSSION}

In present study authors have calculated and compared cost effectiveness of tablet nitrofurantoin with injection ceftriaxone, authors have compared average number of admission (IPD) days of patients receiving tablet nitrofurantoin and injection ceftriaxone as an empirical therapy for urinary tract infections. Percentage of cost of therapy attributed to nitrofurantoin was found to be less than ceftriaxone $(\mathrm{p}<0.05)$ in all the five groups, nitrofurantoin was found to be more cost effective as compared to ceftriaxone in adult UTI patients. In a study Mckinell et al, nitrofurantoin was found to be the most low cost antibiotic used as an empirical therapy in uncomplicated UTI when compared to other antibiotics such as cotrimoxazole and other fluoroquinolones, this study was a cost minimization study and high sensitivity and low resistance of nitrofurantoin was the reason of selecting it as a favourable antibiotic. ${ }^{10}$ However in one study by Lin et al, comparing effectiveness and cost of three antibiotics (ceftriaxone, ertapenem and levofloxacin) ceftriaxone was found to be more cheaper than ertapenem and levofloxacin. ${ }^{11}$ In one study by Bosmans et al, comparing cost effectiveness between cranberry capsules and tablet cotrimoxazole as a prophylactic therapy for recurrent UTI in women, cotrimoxazole was found to be more cost effective. ${ }^{12}$ In a study by Friedland et al, comparing oral cefixime and inj ceftriaxone in adolescents patients suffering from gonococcal cervicitis no cost advantages was seen in between cefixime and ceftriaxone. ${ }^{6}$ In a study by Huang et al, for economic assessment of three antibiotics i.e. ciprofloxacin, cotrimoxazole and nitrofurantoin, cotrimoxazole was found to be more cost effective as compared to other antibiotics. ${ }^{13}$

In a study by Hutner et al, 5 days of nitrofurantoin resulted in significant clinical resolution of uncomplicated UTI in women compared to single dose fosfomycin at $14^{\text {th }}$ and $24^{\text {th }}$ day respectively, however in present study no significant difference was found in between average number of admission (IPD) days in between nitrofurantoin and ceftriaxone. ${ }^{7}$ In a systematic review and meta-analysis by Price et al, comparing prophylactic capacity of nitrofurantoin with other antibiotics, nitrofurantoin had shown similar efficacy to antibiotics such as norfloxacin, cotrimoxazole, cefaclor etc but more adverse effects. ${ }^{14}$

\section{CONCLUSION}

In current study authors found tab nitrofurantoin to be more cost effective than inj ceftriaxone as an empirical therapy in UTI patients however there was no significant difference between the average number of admission (IPD) days in patients receiving Tablet nitrofurantoin and injection ceftriaxone for urinary tract infection as an empirical therapy.

\section{Funding: No funding sources}

Conflict of interest: None declared

Ethical approval: The study was approved by the Institutional Ethics Committee of DMIMS (On 31/03/2017 Ref. No. DMIMS(DU)/IEC/2017-18/6348)

\section{REFERENCES}

1. Urinary Tract Infection: Symptoms, Diagnosis, and Treatment. Healthline. 2015. Available at: https://www.healthline.com/health/urinary-tractinfection-adults. Accessed 8 September 2018.

2. Flores-Mireles AL, Walker JN, Caparon M, Hultgren SJ. Urinary tract infections: epidemiology, mechanisms of infection and treatment options. Nature Reviews Microbiol. 2015 May;13(5):269-84.

3. Epidemiology of urinary tract infections: incidence, morbidity, and economic costs - ScienceDirect. Available at: //www.sciencedirect.com/shttpscience/article/pii/S00 02934302010549 . Accessed 31 August 2018.

4. Vallejo-Torres L, Pujol M, Shaw E, Wiegand I, Vigo JM, Stoddart M, et al. Cost of hospitalised patients due to complicated urinary tract infections: a retrospective observational study in countries with high prevalence of multidrug-resistant Gram-negative bacteria: the Combacte-Magnet, Rescuing study. BMJ Open. 2018 Apr 1;8(4):e020251.

5. Kronenberg A, Bütikofer L, Odutayo A, Mühlemann K, da Costa BR, Battaglia M, et al. Symptomatic treatment of uncomplicated lower urinary tract infections in the ambulatory setting: randomised, double blind trial. BMJ. 2017 Nov 8;359:j4784. 
6. Friedland LR, Kulick RM, Biro FM, Patterson A. Cost-effectiveness decision analysis of intramuscular ceftriaxone versus oral cefixime in adolescents with gonococcal cervicitis. Ann Emergency Med. 1996 Mar 1;27(3):299-304.

7. Huttner A, Kowalczyk A, Turjeman A, Babich T, Brossier C, Eliakim-Raz N, et al. Effect of 5-day nitrofurantoin vs single-dose fosfomycin on clinical resolution of uncomplicated lower urinary tract infection in women: a randomized clinical trial. JAMA. 2018 May 1;319(17):1781-9.

8. Shakti L, Veeraraghavan B. Advantage and limitations of nitrofurantoin in multi-drug resistant Indian scenario. Indian J Med Microbiol. 2015 Oct $1 ; 33(4): 477$.

9. Janodia M, Patel A, Udupa N. Pharmacoeconomics and its applications - emerging role in India. Value Health. 2014 Nov 1;17(7):A796.

10. McKinnell JA, Stollenwerk NS, Jung CW, Miller LG. Nitrofurantoin compares favorably to recommended agents as empirical treatment of uncomplicated urinary tract infections in a decision and cost analysis. Mayo Clin Proc. 2011 Jun 1;86(6):480-8.

11. Lin HA, Yang YS, Wang JX, Lin HC, Lin DY, Chiu $\mathrm{CH}$, et al. Comparison of the effectiveness and antibiotic cost among ceftriaxone, ertapenem, and levofloxacin in treatment of community-acquired complicated urinary tract infections. J Microbiol Immunol Infection. 2016 Apr 1;49(2):237-42.

12. Bosmans JE, Beerepoot MA, Prins JM, ter Riet G, Geerlings SE. Cost-effectiveness of cranberries vs antibiotics to prevent urinary tract infections in premenopausal women: a randomized clinical trial. PloS one. 2014 Apr 4;9(4):e91939.

13. Huang $X$, Hartzema AG, Raasch RH, Kauf TL, Norwood GJ. Economic assessment of three antimicrobial therapies for uncomplicated urinary tract infection in women. Clin Therapeutics. 1999 Sep 1;21(9):1578-88.

14. Price JR, Guran LA, Gregory WT, McDonagh MS. Nitrofurantoin vs other prophylactic agents in reducing recurrent urinary tract infections in adult women: a systematic review and meta-analysis. Am J Obstetr Gynecol. 2016 Nov 1;215(5):548-60.

Cite this article as: Yadav NS, Pathak SS. Cost effective analysis of tab. nitrofurantoin vs. inj. ceftriaxone as an empirical therapy in patients of urinary tract infection at a tertiary health care centre. Int J Basic Clin Pharmacol 2018;7:2393-400. 